\title{
Influence of Tourism Frequency on Association Model of Ecotourism Action
}

\author{
Shwu-Ing $\mathrm{Wu}^{1} \&$ Hao-Ping $\mathrm{Hsu}^{1}$ \\ ${ }^{1}$ Department of Business Administration, National Chin-Yi University of Technology, Taiwan, Republic of \\ China \\ Corresponding: Shwu-Ing Wu, Department of Business Administration, National Chin-Yi University of \\ Technology, Taiping, Taichung, Taiwan, R.O.C. Tel: 886-4-2392-4505.
}

Received: January 30, 2018 Accepted: February 22, 2018 Online Published: February 27, 2018

doi:10.5539/ijms.v10n1p107 URL: https://doi.org/10.5539/ijms.v10n1p107

\begin{abstract}
In recent years, many tour operators have entered to the ecotourism market aiming at the trend of ecotourism. In combination of local ecological and environmental resources, these tour operators have promoted a series of themed ecotourism paths and activities to attract tourists from different places. This study conducted literature review and empirical research to explore the influences of consumers' tourism involvement, tourism values, perception of ecotourism and affection toward ecotourism on attitude toward ecotourism, perceived value of ecotourism, willingness of consumers and actual ecotourism action. Furthermore, association models were established, and the differences on the association models of tourist groups with different tourism frequencies were compared. Convenience sampling was used to survey the consumers who had participated in ecotourism. A total of 787 valid samples were collected. Based on tourism frequency, the respondents were divided into three groups, namely high frequency, medium frequency and low frequency, and the group models were compared. The results showed that (1) the influence of affection toward ecotourism on perceived value of ecotourism is the most significant among the four independent variables in the three tourism groups; (2) for all three tourism groups, tourism involvement has significantly negative influences on the paths of attitude toward ecotourism, and the influence of high-frequency tourism group is the highest; (3) tourism values of the high-frequency tourism group have a significantly negative influence on the path of perceived value of ecotourism while medium-frequency and low-frequency tourism groups have no significant influence; (4) in the medium-frequency tourism group, the affection toward ecotourism has a significantly positive influence on the path of attitude toward ecotourism, and the influence of this group is the highest while high-frequency and low-frequency groups have no significant influence; (5) for all three tourism groups, perceived value of ecotourism has a significantly positive influence on the path of attitude toward ecotourism and the influence of high-frequency tourism group is the highest.
\end{abstract}

Keywords: tourism involvement, tourism values, perception of ecotourism, affection toward ecotourism, attitude toward ecotourism, perceived value of ecotourism, willingness of consumers and actual ecotourism action

\section{Introduction}

In recent years, the tourism awareness has been rising sharply across the world. Since the United Nations set 2002 as the Year of International Ecotourism, Taiwan has corresponded with the international trend and concurrently promoted ecotourism (Tourism Bureau, MOTC, 2002). Aiming at the trend of ecotourism, many tour operators have entered into this market, and utilized local ecological and environmental resources to promote a series of themed ecotourism paths and activities to attract tourists from different places (Fabrício \& Sidnei, 2017).

Ecotourism is a term proposed by Hezter (1965), and is composes of four tourism concepts: tourism should respect the local environment, reduce environmental hazards, create tourist satisfaction and enable the people to acquire perceived value. If all four concepts can be met, ecotourism can bring local economic benefits, protect the local environment, and provide healthy and beneficial tourism activities. Fennell (2001) pointed out that ecotourism generally occurs in natural regions with the objective of offering an opportunity to understand and experience the nature, thus allowing visitors gaining an insight into and contributing to the local cultural conservation. Bjork (2000) suggested that ecotourism emphasizes the concept of sustainability and coexistence. 
It requires a certain understanding of the tourists on the environmental perception, attitude and action in order to achieve the sustainable ecological development. Furthermore, the Tourism Bureau of R.O.C. (2002) defined ecotourism as a type of tourism conducted in natural regions, emphasizing the concept of ecological conservation and adopting sustainable development as the ultimate objective. Ceballos (1987) proposed that ecotourism involves visiting an undestroyed natural region with specific theme in order to enjoy and experience the flora and fauna. To achieve sustainable ecological development and create local economic benefits, the involvement, perception, affection, values, intention and action in ecotourism by consumers should be explored in depth.

Kelly (1983) pointed out that the personal leisure involvement directly influences the perception of intrinsic value. Wiley et al. (2000) indicated that personal involvement is closely related to the attitude toward leisure activities, and further affect the subsequent persistent behavior of visitors. Consequently, tourism involvement of visitors might possibly influence the subsequent attitude and behavior, and thus should be investigated.

Personal attitude and motive toward certain subjects depend on personal values, which further influences inner perception, and values may impact the personal behaviors (Robbins, 2001). As values are the foundation of inner belief, they influence the personal behavior and subsequent decision (Mintz, 1995). As a result, the values of consumers directly influence the attitude and behavior of consumers (Durgee et al., 1996).

Levin \& Chatters (1998) pointed out that personal affection and perception affect the inner individual pleasure. The personal affective connection with ecological environment has a very significant influence on the shaping of ecological environmental value, attitude and belief (Chawla, 1998). Grob (2014) proposed that individuals with rich affections are more likely to participate in relevant ecological environmental activities. Engel (2001) indicated that the factors influencing attitude include affection and perception, and found that attitude is the key element deciding the personal subsequent intention and behavior. Kozak (2001) pointed out that the factors influencing tourism behavior and intention include tourism frequency. As seen, it is important to probe into perception, affection, attitude and tourism frequency in the research of ecotourism (Lucy \& Njoroge, 2018).

Previous researches related to ecotourism mostly focus on the impact of ecotourism development on residents and environments. For instance, Chernela \& Jannetm (2011) investigated the natural and non-natural barriers to ecotourism in Panama. Bascomb, Bobby, Taylor, \& Matthew (2008) probed into the relationship between sustainable development of ecotourism and Maya Region in Guatemala. Only a few studies have explored the influential elements of ecotourism and their association models.

Based on the above, this study generalized the influential factors for actual ecotourism action of consumers into four major elements: tourism involvement, tourism values, perception of ecotourism and affection toward ecotourism in order to probe into their influences on attitude toward ecotourism, perceived value of ecotourism, willingness of consumers and actual ecotourism action. The findings can provide the tour operators and the governmental authorities with suggestions on sustainable development strategies and policies of ecotourism.

In order to effectively segment consumers and improve the accuracy of subsequent strategies and policies for reference of governmental authorities and tour operators, this study investigated the differences in the association models of ecotourism behaviors of consumers with different tourism frequencies, and further probed into the causes. The results can provide tour operators and governmental authorities with reference basis for the establishment of different marketing strategies and service procedures targeted at high-frequency, medium-frequency and low-frequency tourism groups in the future, thereby improving the operational quality and system of ecotourism for building a competitive model.

\section{Literature Review}

\subsection{Tourism Involvement}

"Involvement" refers to the extent to which the individuals feel their interest, demand and value for certain subjects on a spiritual level (Zaichkowsky, 1985). Stone (1984) defined involvement as the responsive behaviors and spiritual feelings of individuals when they are engaged in certain behaviors. Solomon (2004) pointed out that the consumer involvement in certain subjects differs with the invested mental and physical efforts. In addition, the involvement is influenced by the individual characteristics, external stimulation and environmental factors (Bloch \& Richins, 1983). Havitz \& Dimanche (1990) indicated that the leisure involvement refers to the affection, motive and spiritual state of individuals invested in specific tourism.

The personal involvement inventory (PII) proposed by Zaichkowsky (1985) is commonly used as an important tool to speculate and judge the involvement. PII divides the consumer involvement into four dimensions, namely importance, relevance, hedonic value and attitude. It also applies 7-point semantic differential method to 
measure the consumer involvement. Laurent \& Kapferer (1985) developed the consumer involvement profile (CIP) to divide the consumer involvement into five dimensions, namely importance, pleasure, individual values, risk probability and risk importance. Kyle and Mowen (2005) adopted attraction, centrality, self-expression and social association as the involvement dimensions. Based on Laurent \& Kapferer (1985) and Kyle \& Mowen (2005), this study developed the dimensions of consumer involvement inventory and adopted tourism importance, tourism leisure, tourism attraction and tourism social association as the measurement variables on consumer tourism involvement.

\subsection{Tourism Values}

Values refer to the views of individuals on surrounding environments or targets (Schwartz, 1992). Mintz (1995) pointed out that values are the foundation of individual spiritual belief and spur individuals to make different behaviors and decisions. Furthermore, individual attitudes and behaviors are influenced by values (Durgee et al., 1996). Zins (1998) indicated that as a belief, values can promote individual demands, feelings and desires to develop into attitudes. Engel, Blackwell \& Miniard (2001) presented that values are the development center of personality structure and that a belief that is deeply embedded in individuals will not easily change. Robbins (2001) noted that values are the long-term belief of individuals and describe the final states of certain behaviors or subjects.

Rokeach (1973) indicated that personal values can be divided into two sub-dimensions, namely instrumental and purpose dimensions, and then developed 36 items to explain the values of consumers. Schwartz (1992) mentioned that values play a significant role in decision-making of consumers. In the value measurement profile proposed by Schwartz, the values are divided into ten types revealing motives and values, namely power, achievement, hedonism, stimulation, self-orientation, world peace, mercy, tradition, obedience and safety. In reference to the measurement items proposed by Schwartz (1992), this study adopted hedonism, stimulation, achievement and self-orientation as the indicators measuring the tourism values of consumers.

\subsection{Perception of Ecotourism}

Perception refers to a period in which the individuals receive subjects and information from external environments and then arrange the information inwards and finally form individual opinions on this subject (Reed, 2012). Kotler (2009) thought that perception is an inner processing period of individuals based on information selection, organization and interpretation, Fisher, Bell, \& Baum (1984) considered perception as views of individuals on certain subjects after the individuals convert the received information mentally, and then organize and arrange the information.

Buckley (1994) measured perception of ecotourism by dividing it into four dimensions, namely natural resources, conservation support, environmental education and sustainable operation. Based on those measurement dimensions, this study adopted the environmental ethics, environmental education and sustainable operation of tourists on ecotourism as the measurement variables on the consumers' perception of ecotourism.

\subsection{Affection toward Ecotourism}

Affection refers to the subjective feelings on certain subjects that individuals are exposed to, including love and hate (Rosenberg \& Hanland, 1960). In addition, affection is an inward integrated feeling containing emotions, feelings and potential attitudes (Bagozzi et al., 1999). Hanna \& Wozniak (2001) pointed out that affection is the feeling of individuals on certain target subjects, including love and hate; and is an overall feeling of individual sentiment, mood and memory (Arnould et al., 2004). Affection is inner order and perception state related to individual experience, mood and emotion, and can demonstrate the value of external subjects for individuals and express personal preferences (Frijda, 1993).

King \& Meiselman (2010) measured affection by dividing it into two dimensions, namely positive \& negative, and happy \& unhappy dimensions. Mehrabian \& Russell (1974) proposed three dimensions of emotion based on environmental psychology, namely pleasure, arousal and dominance (PAD). However, Russell \& Pratt (1980) indicated that the measurement of environmental emotion only requires arousal and pleasure. Based on Mehrabian \& Russell (1974) and Russell \& Pratt (1980) on emotion measurement, this study developed pleasure and arousal dimensions to measure the response of tourists to affection toward ecotourism.

\subsection{Attitude toward Ecotourism}

Attitude refers to negative and positive views of consumers on certain subjects (Eagles \& Blackwell, 1995). The attitude of consumers is composed of previous individual experience, habit and knowledge acquisition, and influences the personal preference and evaluation on certain subjects. Zajonc (1982) pointed out that individual attitude is stimulated by people and subjects, and thus affects the different personal responses and actual 
behaviors. Therefore, attitude reflects personal preference and dislikes for certain subjects, and influences the subsequent intention and behavior (Blackwell, 2001).

Weber (1991) proposed that attitude contains perception, affection and action tendency. Ragheb \& Beard (1982) developed the leisure attitude scale (LAS) to serve as the basis for measuring people's leisure attitude, and divided leisure attitude into three major hierarchies, namely perception, affection and behavior. Based on the LAS proposed by Ragheb \& Beard (1982), this study adopted perception, affection and behavior as the measurement variables on the attitude toward ecotourism of tourists.

\subsection{Perceived Value of Ecotourism}

Value refers to comparison result between the personal cost and the acquired achievement. Generally, consumers tend to convert tangible commodities and intangible service sensory experience into subjective perceived value (Zeithaml, 1988; Kotler, 2009). Perceived value refers to the equivalent relation between costs and gains evaluated by the consumers when they are purchasing products or services (Hellier et al., 2003). Therefore, value is the balance between gains and costs, and do not differ with different consumer perceptions (Lovelock, 2004). Assael (1998) pointed out that the consumer perceived value is positively correlated to the consumers' intention to purchase subsequent products.

Sheth, Newman, \& Gross (1991) divided the perceived value into five categories, namely social value, affective value, functional value, perceptive value and conditional value. Grewal, Monroe, \& Krishann (1998) measured the perceived value from two dimensions. Specifically, the first dimension is the material value for consumers on interest hierarch; the second dimension is the transaction value for consumers on spiritual hierarchy. Sweeney \& Soutar (2001) divided perceived value into four dimensions, respectively emotional value, social value, price functional value and quality functional value. Petrick (2002) divided the perceived service value into five dimensions, namely quality, affective response, currency value, behavioral value and goodwill. Based on Sheth, Newman, \& Gross (1991) and Petrick (2002), this study adopted social value, affective value, functional value and perceptive value as the measurement variables on consumers' perceived value of ecotourism.

\subsection{Willingness of Consumers}

Willingness refers to judgmental intention of individuals to take certain behaviors in the future based on previous perception (Folkes, 1988). Engel, Black, \& Miniard (2001) defined willingness as the tendency and behavior of individuals to engage into certain affairs in the future. Therefore, tourism willingness refers to the possibility of tourist to select certain specific tourism themes (Pike \& Ryan, 2004), and is closely related to the subsequent consumer use or purchase behavior (Schiffman \& Kanuk, 2000). It varies according to consumers' previous tourism experience (Horng, Liu, Chou, \& Tsai, 2012).

Zeithaml (1988) measured the purchase intention from three dimensions, namely possible purchase, intended purchase and considered purchase. Boulding, Kalra, Staelin, \& Zeithaml (1993) probed into the purchase intention from two dimensions, namely repurchase intention and recommendation intention. Zeithaml, Berry, \& Parasuraman (1996) measured the behavioral intention from four dimensions, namely reputation communication, repurchase intention, price sensitivity and complaint behavior, and further distinguished between beneficial and harmful behavioral intention. Specifically, the beneficial intention includes repurchase intention, recommendation intention and loyalty while the harmful intention includes complaint, negative reputation and departure. In reference to the measurement dimensions on consumer purchase intention proposed by Zeithaml (1988) and Boulding et al. (1993), this study adopted tourist participation intention and recommendation intention as two measurement variables to investigate the willingness of consumers.

\subsection{Actual Ecotourism Action}

Davis (1989) defined actual using behavior as the extent to which the consumers intend to use and use certain subjects. Shim, Eastlick, Lotz, \& Warrington (2001) proposed that the actual consumption behaviors of consumers originate from behavioral intention, which means that behavioral intention is the individual subject view and influences the individual decision on actual subsequent behaviors ( $\mathrm{Wu}, 2006)$. Through practical and theoretical investigation, many studies have demonstrated that there is a precedence relation between behavioral intention and actual behavior (Sia, Lim, Leung, Lee, Huang, \& Benbasat, 2009; Wu, 2006). Therefore, behavioral intention can be regarded as the measurement indicator for actual behavior (Fishbein \& Ajzen, 1980).

Ajzen \& Fishbein (1980) proposed the Theory of Reasoned Action (TRA) and difined individual behaviors by two phases, namely behavior intention and actual behavior. Behavioral intention probes into the influence of attitude on the formation of individual behavior; actual behavior represents certain behavior of individuals under reason, namely the condition about action that is actually taken. Park (1996) adopted participation frequency, 
event duration and event intensity as the measurement variables. The event participation frequency can effectively measure the participation behavior (Iwasaki \& Havitz, 2004). Funk et al. (2004) pointed out that consumption behavior is one of the behavior measurement indicators, which means that consumers with deep participation are more intended to invest more capital in participating in actions. Based on Park (1996), Iwasaki \& Havitz (2004), and Funk et al (2004), this study developed the actual tourism action measurement profile, and adopted actual event participation duration and frequency as two measurement variables to probe into the actual ecotourism actions of consumers.

\subsection{Behavioral Segmentation}

Smith (1994) pointed out that segmentation is to distinguish different consumer demands on a market level and regard consumers of the same segment as a sub-market for convenience of adjusting product and marketing strategies. In addition, consumers can be segmented by demographic statistics variable, geographic variable, psychological variable and behavioral variable (Wells \& Prensky, 1996). Effective market segmentation can ensure competitive advantages and the difference from competitors (Mulhern, 1999). Therefore, this study segmented the consumers by ecotourism frequency, and probed into the differences among consumers with different tourism frequencies.

\section{Research Hypotheses}

\subsection{Influence of Tourism Involvement on Attitude toward Ecotourism and Perceived Value of Ecotourism}

Consumer attitude is shaped by environmental interaction, learning and development of individuals (Wiley, Shaw \& Havitz, 2000). Swanson (1974) pointed out that consumer involvement influences the using attitude of individuals toward certain subjects. Petty \& Cacioppo (1986) proposed the elaboration likelihood model (ELM) to demonstrate that the consumer involvement leads to different attitudes. Andrews, Durvasula, \& Akhter (1990) demonstrated the ELM theory using beer advertisements. They found that the attitude of high-message involvers is easily influenced by the argument intensity, while the attitude of low-message involvers is easily influenced by the persuasion of brand endorsers. It can be inferred from above that the tourism involvement of consumers influences their attitude toward ecotourism. Therefore, following hypothesis is proposed:

Hla: Tourism involvement of consumers has a significantly positive influence on the attitude toward ecotourism.

Havitz \& Dimanche (1990) indicated that leisure involvement refers to an abstract and unobservable motivational behavior or anxious and interested state. It is also related to perceptive risk. Individuals with high involvement have a higher perceptive risk compared to that of individuals with low involvement (Scuett, 1993). Swinyard (1993) studied related product use and service and found that individuals with high involvement tend to value the commodity use and service experience more than individuals with low involvement, thus concluding that consumer involvement influences perceived value. Kelly (1983) pointed out that involvement of leisure event participants directly influences their value acquisition. It can be inferred from above that tourism involvement of consumers influences their perceived value of ecotourism. Therefore, following hypothesis is proposed:

Hlb: Tourism involvement of consumers has a significantly positive influence on their perceived value of ecotourism.

\subsection{Influence of Tourism Values on Attitude toward Ecotourism and Perceived Value of Ecotourism}

Williams (1979) pointed out that individuals differ in attitudes and behaviors toward others when their values differ. The consumer attitude is influenced by different individual values, and then directly affects subsequent decisions and behaviors (Kahle \& Homer, 1988). Homer \& Kahle (1988) indicated in the research on consumer behaviors that personal values are highly related to the attitude toward health and foods, and validated that attitude serves as a mediating variable and indirectly affects subsequent consumption behaviors. Rokeach (1973) pointed out that values affect indirectly the decision-making of consumers via their attitude toward target. It can be inferred from above that the tourism values of consumers affects their attitude toward ecotourism. Therefore, following hypothesis is proposed:

\section{H2a: Tourism values of consumers have a significantly positive influence on their attitude toward ecotourism.}

Feather \& Rauter (2004) indicated that the working values are affecting individuals' perception and evaluation on their work. Pine \& Innis (1987) pointed out that the perception and satisfaction that individuals form during working are affected by their values. Robbins (2001) suggested that values serve as the foundation for the understanding of consumer attitude and motive, and affect the consumer perception on organizations and products. Singhapakdi \& Vitell (1993) concluded that professional ethics perception differs with individual 
values and affects individual moral judgment. Previous research verified that the values of consumers result in differences in inner perception and personal values $(\mathrm{Li}, 2010)$. It can be inferred from above that the tourism values of consumers affects their perceived value of ecotourism. Therefore, following hypothesis is proposed:

H2b: Tourism values of consumers have a significantly positive influence on their perceived value of ecotourism.

\subsection{Influence of Perception of Ecotourism on Attitude toward Ecotourism and Perceived Value of Ecotourism}

Barbaro, Pickett, \& Parkhill (2015) probed into how the environmental attitude regulates the association between cognitive demand and environmental objective selection, and found that people's ecological perception positively affects their environmental attitude and objective selection. Smith (1994) found in a consumer research that individuals with higher perception concerning one certain affair have a stronger attitude toward this affair. Petty, Cacioppo, Kao, \& Rodrigues (1986) indicated that individuals with higher perception more easily consider and elaborate the message when forming their attitude compared to individuals with lower perception. It can be inferred from above that perception of ecotourism of consumers has a significantly positive influence on their attitude toward ecotourism. Therefore, following hypothesis is proposed:

H3a: Perception of ecotourism of consumers has a significantly positive influence on their attitude toward ecotourism.

Weber (1991) pointed out that cognition, perception and behavior mutually influence each other. Dodds (1985) indicated that cognitive quality positively affects the perceived value. Bjorner et al. (2004) found in their research on association of environmental labels and consumers that the perceived risk of consumers can be reduced by presenting consumers with access to trustworthy information about environmental commodities. It can be inferred from above that perception of ecotourism of consumers has a significantly positive influence on their perceived value of ecotourism. Therefore, following hypothesis is proposed:

H3b: Perception of ecotourism of consumers has a significantly positive influence on their perceived value of ecotourism.

\subsection{Influence of Consumers' Affection toward Ecotourism on Attitude toward Ecotourism and Perceived Value of Ecotourism}

Affection is an inward integrated feeling containing emotions, feelings and potential attitudes (Bagozzi et al., 1999). Blackwell, Miniard, \& Engel (2001) pointed out that individual affection affects individual attitude, and affection is a key factor affecting attitude. Burke \& Chapman (1987) proposed that when watching the product advertisement, consumers directly generate negative and positive affections, which serve as important antecedent to forecast the advertisement effect and the attitude of consumers toward product. Smith \& Swinyard (1982) mentioned that strong affections of consumers influence their preference and attitude toward commodities. Sutton, Milin, McDonald, \& Cimperman (1997) pointed out that fans with stronger affections possess more positive attitude, and are more willing to invest time and money into sports events. It can be inferred from above that consumers' affection toward ecotourism has a significantly positive influence on their attitude toward ecotourism. Therefore, following hypothesis is proposed:

H4a: Consumers' affection toward ecotourism has a significantly positive influence on their attitude toward ecotourism.

Sherry (1990) indicated that emotions of consumers directly affect their perceived value. Babin and Darden (1995) found that the pleased emotion of consumers due to possession of certain commodities is significantly and positively related to perceived value. Hirschman \& Holbrook (1982) pointed out that the feelings that consumers acquire during purchasing are significantly and positively related to the perceived hedonic value. It can be inferred from above that consumers' affection toward ecotourism has a significantly positive influence on their perceived value of ecotourism. Therefore, following hypothesis is proposed:

H4b: Consumers' affection toward ecotourism has a significantly positive influence on their perceived value of ecotourism.

\subsection{Influence of Consumers' Perceived Value of Ecotourism on Attitude toward Ecotourism}

Johnson et al. (2006) indicated that factors affecting brand attitude and loyalty include perceived value, affective commitment and brand equity, and perceived value has a significantly positive influence on the brand equity. However, in related researches on ecotourism perception and attitude, Madrigal (1995) pointed out that residents who possess negative tourism perception have a higher tendency to add sightseeing limiting taxation. MaCarthy \& Shrum (1994) indicated that when the consumers realize commodity and service value, their attitude toward this commodity is influenced, which further affect the subsequent purchase intention. It can be inferred from 
above that perceived value of ecotourism of consumers has a significantly positive influence on their attitude toward ecotourism. Therefore, following hypothesis is proposed:

H5: Perceived value of ecotourism of consumers has a significantly positive influence on their attitude toward ecotourism.

\subsection{Influence of Attitude toward Ecotourism on Willingness of Consumers}

Attitude reflects individuals' preference for certain target. If individuals have an excellent attitude toward certain target and possess this demand, purchase intention is further generated (Ajzen \& Fishbein, 1980). Cronin \& Taylor (1992) pointed out that customers hold different attitudes toward certain commodity or service based on previous experience, which affect their purchase intention. Lafferty, Goldsmith, \& Newell (2002) found that advertisement and brand attitudes directly impose a significantly positive influence on the purchase intention of consumers. Lai \& Nepal (2006) indicated that the attitude of community residents affects the protection of natural resources, conservation of cultural traditions, development of sustainable community, and participation intention in ecotourism. Yoon et al. (2001) found in the research on sightseeing development that local residents' positive and supportive attitude toward sightseeing affects their subsequent support and participation intention of sightseeing development. It can be inferred from above that consumers' attitude toward ecotourism has a significantly positive influence on the willingness of consumers. Therefore, following hypothesis is proposed:

H6: Consumers' attitude toward ecotourism has a significantly positive influence on their willingness.

\subsection{Influence of Perceived Value of Ecotourism on Willingness of Consumers}

The transaction utility theory proposed by Thaler (1985) suggests that perceived value positivelys affect the purchase intention of customers. Kumar et al. (2009) indicated that the forecast of consumer purchase intention depends on the perceived value of certain target. Ponte et al. (2015) and Lien et al. (2015) probed into Internet tourism commodity purchase, and found that perceived value of consumers has a significantly positive influence on their purchase intention. Petrick (2002) proved that perceived value has a significantly positive influence on the purchase intention. Hence, perceived value is a critical indicator for forecasting subsequent intention and behavior of consumers (Cronin, Brady, \& Hult, 2000). It can be inferred from above that perceived value of ecotourism of consumers has a significantly positive influence on the willingness of consumers. Therefore, following hypothesis is proposed:

H7: Perceived value of ecotourism of consumers has a significantly positive influence on their willingness.

\subsection{Influence of Willingness of Consumers on Actual Ecotourism Action}

Engel, Backwel, \& Miniard (2001) pointed out that the relationship between behavioral intention and behavior is more direct than the relationships between perception, affection or attitude and actual action, and that behavioral intention is a key factor in forecasting actual action. Therefore, purchase intention of consumers can forecast the subsequent purchase behavior of consumers (Morwitz \& Schmittlein, 1992). Venkatesh \& Agarwal (2006) found that there is a significantly positive correlation between behavioral intention and actual action. Zeithaml, Berry, \& Parasuraman (1996) studied the service quality behaviors, and indicated that negative and positive behavioral intention is the judgment indicator for future purchase behavior of consumers. Therefore, it can be inferred that willingness of consumers has a significantly positive influence on their actual ecotourism action. Therefore, following hypothesis is proposed:

H8: Willingness of consumers has a significantly positive influence on their actual ecotourism action.

\subsection{Comparison of Influences of Different Tourism Frequencies on Association Model of Ecotourism Action}

Losada, Alen, Domínguez, \& Nicolau (2016) pointed out that groups with different tourism frequencies differ significantly in gender, monthly income and tourism frequency. Specifically, consumers with higher income and educational background are more intended to increase their time on tourism, leading to higher tourism frequency (Zhan, Yan, Zhu, \& Wang, 2016). Elias, Benjamin, \& Shiftan (2015) found in the research on tourism behavior that the tourism frequency and duration of males are generally higher than those of females. In addition, consumers with higher tourism frequency tend to arrangement longer duration of stay in order to conduct more diversified tourism events. It can be inferred from above that groups with different tourism frequencies differ in the association model of ecotourism action. Therefore, following hypothesis is proposed:

H9: Groups with different tourism frequencies differ in the path and association intensity of association model of ecotourism action. 


\section{Research Design}

\subsection{Research Framework}

This study first reviewed related theories and literature, and developed the research structure. Then, it conducted questionnaire survey to explore the influences of tourism involvement, tourism values, perception of ecotourism and affection toward ecotourism on attitude toward ecotourism, perceived value of ecotourism, willingness of consumers and actual ecotourism action. It then probed into the influences of the path and association intensity of association model on ecotourism action for groups of different tourism frequencies (as shown in Fig.1). The sampled population was consumers over the age of 15 in Taiwan.

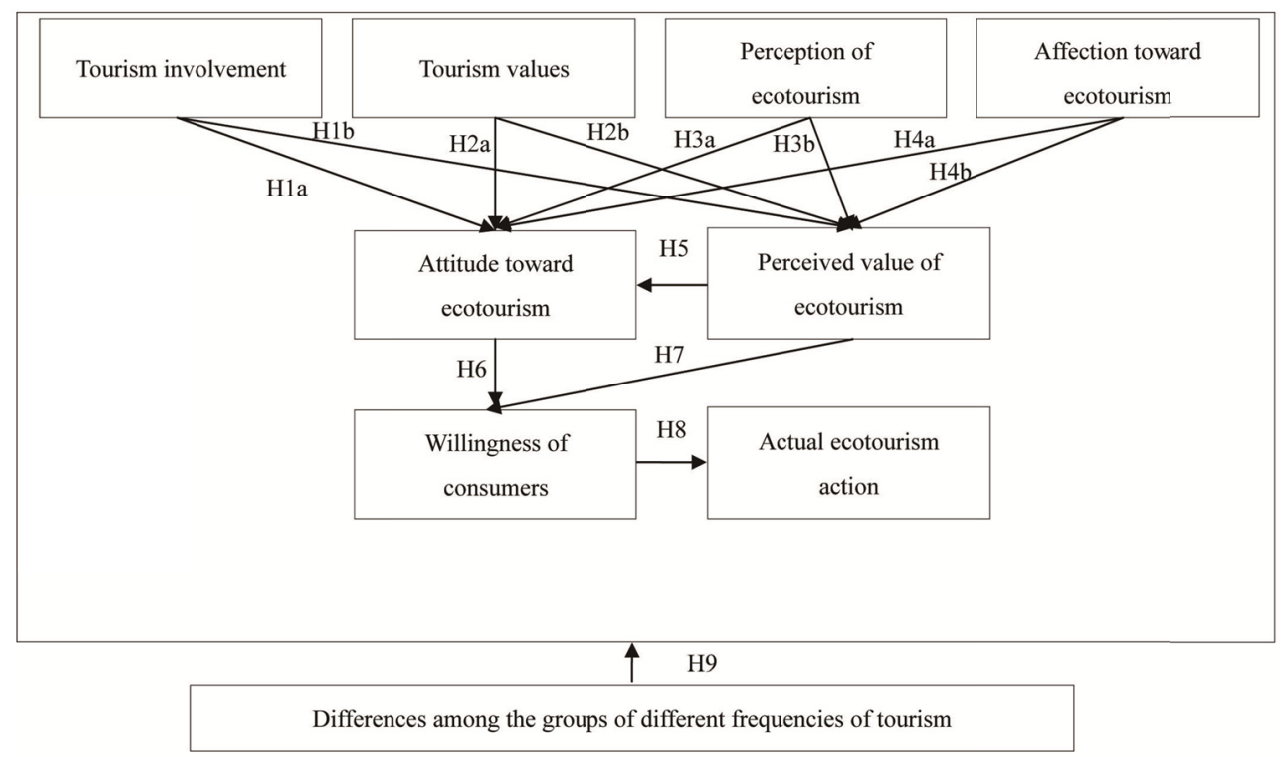

Figure 1. Research framework

\subsection{Research Method and Procedures}

This study developed the questionnaire draft based on related theories and literature. The questionnaire was modified based on expert opinions and trial test results. Convenience sampling was used in the questionnaire survey, and the researcher distributed and collected the questionnaires in person. The subjects were Taiwanese consumers, over 15 years old, who had participated in ecotourism.

\subsection{Sample Structure}

A total of 800 questionnaires were distributed to people who had participated in ecotourism in the past. After removing 13 invalid samples, there were 787 effective samples, with a valid return rate of $98.3 \%$. Among the respondents, most of them are 25 34 years old (25.9\%), followed by 35 44 years old (25.0\%). In terms of place of residence, most of them live in northern Taiwan (41.3\%), followed by central Taiwan (30.6\%). As for educational level, most of them have a bachelor degree (64.7\%), followed by senior high school degree or higher vocational degree $(20.6 \%)$. In the aspect of occupation, most of them work in the service industry (26.4\%), followed by the manufacturing industry (16.1\%). Most of them have an average monthly income between NTD 20,001 and NTD 40,000 (49.3\%), followed by below NTD 20,000 (26.7\%). In terms of ecotourism participation, most of them participate $0-2$ times per year $(79.0 \%)$, followed by 3-5 times per year $(16.0 \%)$. As for ecotourism frequency, most of them participate in ecotourism once each half year $(40.0 \%)$, followed by once a year (33.5\%). Most of them participate in ecotourism due to proximity to nature (27.8\%), followed by stress relief $(21.6 \%)$.

\subsection{Reliability and Validity Analysis}

This study used Cronbach's $\alpha$ value and factor analysis to evaluate the reliability and validity of the questionnaire. Nunnally (1978) proposed that a Cronbach's $\alpha$ larger than 0.7 indicates a high internal consistency, which means high reliability. Kerlinger (1978) suggested that the item-to-total correlation coefficient should be larger than 0.5 . In this study, the Cronbach's $\alpha$ value and correlation coefficient on each dimension conformed to the standards, indicating good reliability, as shown in Table 1. 
Factory analysis was adopted to examine the convergent validity of the questionnaire. The main component analysis method was used to extract the factors whose eigenvalue is larger than 1 . Based on the varimax analysis, the variables under six dimensions, including tourism values, perception of ecotourism, ecological environment affection, attitude toward ecotourism, willingness of consumers and actual ecotourism action, were classified into the same factor. The factor loadings of each variable in each factor were larger than 0.5 . The factors whose factor loadings are smaller than 0.4 were removed. Thus, the tourism involvement and perceived value of ecotourism were divided into two factors each. The two factors in tourism involvement were named as hedonism involvement and social connection involvement respectively. The two factors in perceived value of ecotourism were respectively named as functional cognitive value and interpersonal affective value. The accumulated explained variance of each factor was larger than $50 \%$. All the factor dimensions of the questionnaires have convergent validity, as shown in Table 1.

The reliability and validity were evaluated based on composite reliability (CR) and average variance extraction (AVE) of latent variables. The judgment principle was that CR is larger than 0.6 and AVE is larger than 0.5 (Fornell \& Larcker, 1981). The CR of latent variables in each factor ranged between 0.8542 and 0.9547 , all larger than 0.6 , which indicates that the factor dimensions of this study possess good internal consistency. The average variance extraction of latent variables ranged between 0.5507 and 0.8384 , all larger than 0.5 , which meet the criteria. In other words, all the factors have convergent validity, as shown in Table 1.

According to Gaski \& Nevin (1985), correlation analysis was used in this study to evaluate the principle that the discriminant validity of dimensions in the questionnaire should be the correlation coefficient between any two dimensions and smaller than Cronbach's $\alpha$ value of individual dimensions. Moreover, the square root of average variance extraction of all the variables should be larger than the correlation coefficient between the corresponding variables (Fornell \& Larcker, 1981). The results validated that the correlation coefficient of dimensions on each factor in this study conformed to above standards, which indicates that the factor dimensions in the questionnaire have discriminant validity.

Table 1. Analysis of reliability and validity of formal questionnaire

\begin{tabular}{|c|c|c|c|c|c|c|c|c|}
\hline Factor and item & Mean & $\begin{array}{l}\text { Item-to-total } \\
\text { correlation } \\
\text { coefficient }\end{array}$ & $\begin{array}{l}\text { Factor } \\
\text { loading }\end{array}$ & Eigenvalue & $\begin{array}{l}\text { Cumulative } \\
\text { explained } \\
\text { variation \% }\end{array}$ & $\begin{array}{l}\text { Cronbach } \\
\alpha \\
\text { value }\end{array}$ & $\begin{array}{l}\text { Composite } \\
\text { reliability } \\
\text { (CR) }\end{array}$ & $\begin{array}{l}\text { Average } \\
\text { variance } \\
\text { extraction } \\
\text { (AVE) }\end{array}$ \\
\hline $\begin{array}{l}\text { Tourism is an indispensable activity for } \\
\text { me }\end{array}$ & 5.69 & .832 & .825 & 6.086 & 50.716 & .951 & 0.9376 & 0.6255 \\
\hline Tourism is an important activity for me & 5.84 & .810 & .818 & & & & & \\
\hline $\begin{array}{l}\text { Tourism is an activity which can satisfy } \\
\text { me the most }\end{array}$ & 5.46 & .801 & .778 & & & & & \\
\hline I can gain many joys from tourism & 6.18 & .778 & .775 & & & & & \\
\hline Tourism is attractive to me & 5.90 & .804 & .775 & & & & & \\
\hline $\begin{array}{l}\text { Tourism is the biggest motive source for } \\
\text { me }\end{array}$ & 5.44 & .788 & .774 & & & & & \\
\hline \multicolumn{9}{|c|}{ Tourism involvement (Social connection involvement ) } \\
\hline $\begin{array}{l}\text { Tourism gives me an opportunity to get } \\
\text { along with friends }\end{array}$ & 5.73 & .827 & .904 & 2.834 & 74.336 & .873 & 0.8542 & 0.6665 \\
\hline $\begin{array}{l}\text { Tourism activities can improve } \\
\text { inter-personal relationships }\end{array}$ & 5.79 & .780 & .884 & & & & & \\
\hline $\begin{array}{l}\text { I like talking about tourism with family } \\
\text { and friends }\end{array}$ & 5.67 & .667 & .633 & & & & & \\
\hline \multicolumn{9}{|l|}{ Tourism values } \\
\hline I feel I can gain a lot from tourism & 5.96 & .808 & .870 & 4.828 & 68.977 & .925 & 0.9395 & 0.6897 \\
\hline Tourism can give me pleasure & 6.00 & .787 & .857 & & & & & \\
\hline $\begin{array}{l}\text { I take delight in enjoying tourism } \\
\text { process }\end{array}$ & 6.06 & .781 & .855 & & & & & \\
\hline Tourism makes me feel accomplished & 5.55 & .765 & .824 & & & & & \\
\hline $\begin{array}{l}\text { Tourism is an important objective of my } \\
\text { life }\end{array}$ & 5.31 & .738 & .802 & & & & & \\
\hline
\end{tabular}




\begin{tabular}{|c|c|c|c|c|c|c|c|c|}
\hline $\begin{array}{l}\text { I can explore new things in tourism } \\
\text { I can show my own characteristics } \\
\text { during tourism }\end{array}$ & $\begin{array}{l}5.99 \\
5.35\end{array}$ & .717 & $\begin{array}{l}.801 \\
.801\end{array}$ & & & & & \\
\hline \multicolumn{9}{|l|}{ Perception of ecotourism } \\
\hline $\begin{array}{l}\text { I learn to cherish nature and ecological } \\
\text { environment from tourism }\end{array}$ & 6.61 & .838 & .880 & 6.309 & 70.100 & .946 & 0.9547 & 0.701 \\
\hline $\begin{array}{l}\text { Protect ecological environment during } \\
\text { tourism }\end{array}$ & 6.56 & .817 & .863 & & & & & \\
\hline $\begin{array}{l}\text { Formulate related statutes and } \\
\text { regulations on ecological conservation }\end{array}$ & 6.54 & .813 & .858 & & & & & \\
\hline $\begin{array}{l}\text { Consider the living habits of wild } \\
\text { animals and plants }\end{array}$ & 6.47 & .799 & .845 & & & & & \\
\hline $\begin{array}{l}\text { Conserve natural resources and create } \\
\text { sustainable operation }\end{array}$ & 6.55 & .786 & .836 & & & & & \\
\hline Consider bearing capacity & 6.53 & .787 & .834 & & & & & \\
\hline It is immoral to destroy natural ecology & 6.62 & .771 & .825 & & & & & \\
\hline $\begin{array}{l}\text { Persuade tourists by environmental } \\
\text { education }\end{array}$ & 6.31 & .765 & .812 & & & & & \\
\hline $\begin{array}{l}\text { Interpretation education is important to } \\
\text { educational tourism }\end{array}$ & 6.32 & .727 & .778 & & & & & \\
\hline \multicolumn{9}{|l|}{ Affection toward ecotourism } \\
\hline $\begin{array}{l}\text { Environment in ecotourism makes me } \\
\text { joyful }\end{array}$ & 6.05 & .880 & .924 & 4.626 & 77.108 & .940 & 0.9527 & 0.771 \\
\hline $\begin{array}{l}\text { Environment in ecotourism makes me } \\
\text { pleased }\end{array}$ & 6.09 & .862 & .911 & & & & & \\
\hline $\begin{array}{l}\text { Environment in ecotourism makes me } \\
\text { interested }\end{array}$ & 5.96 & .829 & .883 & & & & & \\
\hline $\begin{array}{l}\text { Environment in ecotourism makes me } \\
\text { feel at ease }\end{array}$ & 6.01 & .809 & .871 & & & & & \\
\hline $\begin{array}{l}\text { Environment in ecotourism makes me } \\
\text { amazed }\end{array}$ & 6.03 & .797 & .859 & & & & & \\
\hline $\begin{array}{l}\text { Environment in ecotourism stimulates } \\
\text { my moved emotion }\end{array}$ & 5.76 & .744 & .816 & & & & & \\
\hline \multicolumn{9}{|l|}{ Attitude toward ecotourism } \\
\hline I like participating in ecotourism & 5.79 & .840 & .879 & 6.150 & 68.335 & .942 & 0.951 & 0.6832 \\
\hline $\begin{array}{l}\text { I will increase my time spent on } \\
\text { ecotourism }\end{array}$ & 5.66 & .816 & .853 & & & & & \\
\hline $\begin{array}{l}\text { Ecotourism contributes to relieving my } \\
\text { pressure }\end{array}$ & 6.15 & .771 & .835 & & & & & \\
\hline Ecotourism can make me fully focused & 5.67 & .779 & .831 & & & & & \\
\hline Ecotourism can make me relaxed & 6.04 & .769 & .831 & & & & & \\
\hline Ecotourism benefits health & 6.18 & .746 & .813 & & & & & \\
\hline Ecotourism can help me grow & 5.99 & .753 & .813 & & & & & \\
\hline I will put ecotourism as my priority & 5.19 & .767 & .806 & & & & & \\
\hline $\begin{array}{l}\text { I am busy but I will participate in } \\
\text { ecotourism }\end{array}$ & 5.08 & .729 & .774 & & & & & \\
\hline \multicolumn{9}{|c|}{ Perceived value of ecotourism (Functional cognitive value) } \\
\hline $\begin{array}{l}\text { Ecotourism can enable me to obtain } \\
\text { knowledge about ecology and } \\
\text { environment }\end{array}$ & 6.06 & .756 & .855 & 4.978 & 41.483 & .940 & 0.9061 & 0.5507 \\
\hline $\begin{array}{l}\text { Ecotourism is a tourism type worth } \\
\text { promoting }\end{array}$ & 5.94 & .787 & .836 & & & & & \\
\hline $\begin{array}{l}\text { Ecotourism can enable me to pursue } \\
\text { related ecological information more }\end{array}$ & 5.86 & .772 & .816 & & & & & \\
\hline $\begin{array}{l}\text { Ecotourism is a meaningful tourism } \\
\text { product }\end{array}$ & 5.87 & .833 & .813 & & & & & \\
\hline Ecotourism can make me relaxed & 5.73 & .795 & .652 & & & & & \\
\hline $\begin{array}{l}\text { Ecotourism can bring me more } \\
\text { happiness }\end{array}$ & 5.65 & .812 & .646 & & & & & \\
\hline $\begin{array}{l}\text { Ecotourism has a value higher than } \\
\text { other tourism types }\end{array}$ & 5.56 & .744 & .640 & & & & & \\
\hline Ecotourism can increase the value of life & 5.59 & .784 & .630 & & & & & \\
\hline \multicolumn{9}{|c|}{ Perceived value of ecotourism (Interpersonal affective value) } \\
\hline $\begin{array}{l}\text { Ecotourism will improve others' views } \\
\text { on me }\end{array}$ & 4.92 & .814 & .891 & 4.085 & 75.526 & .911 & 0.8841 & 0.6594 \\
\hline
\end{tabular}




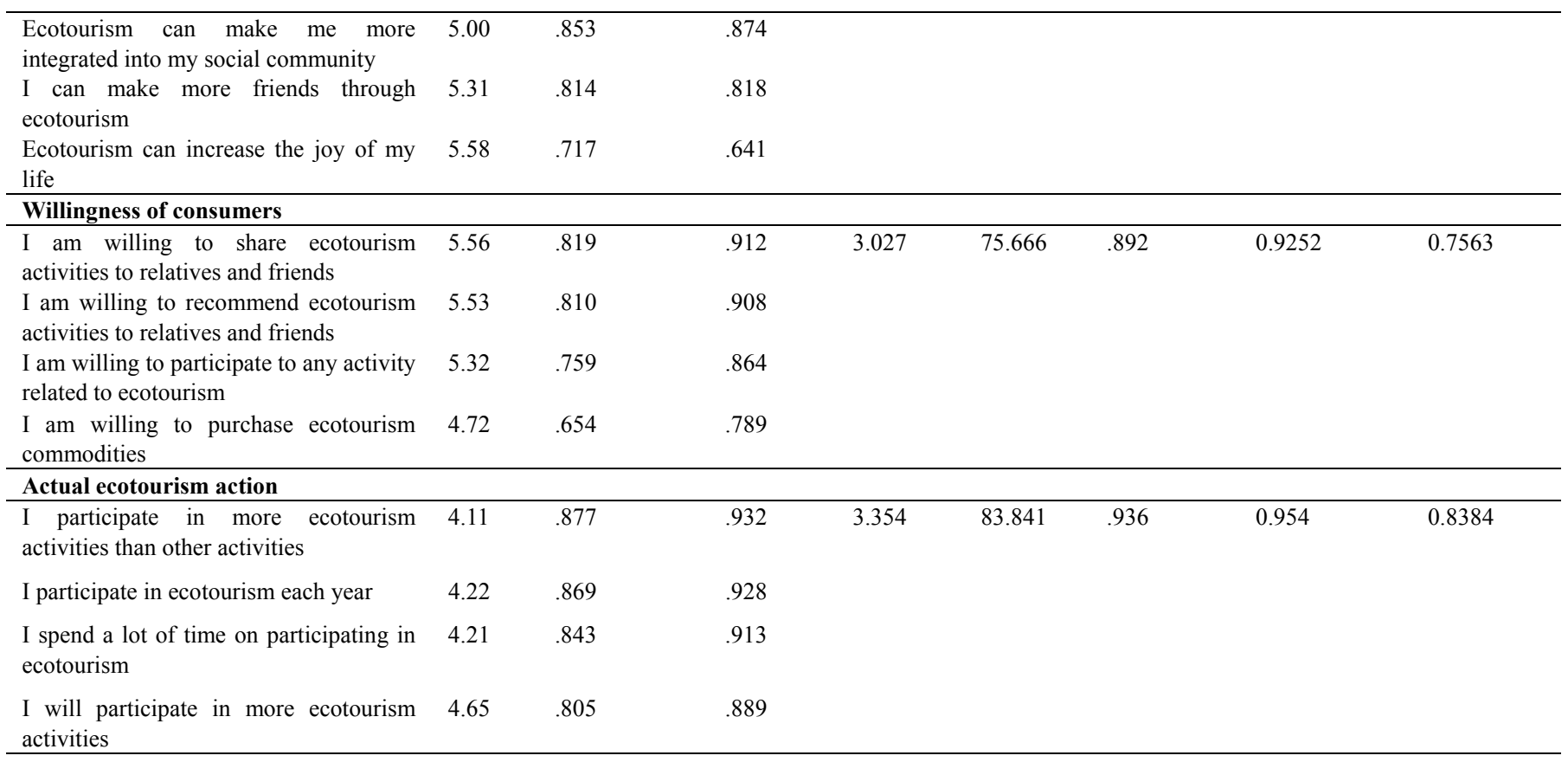

\subsection{Confirmatory Factor Analysis}

To confirm the efficiency of measurement dimensions, this study conducted confirmatory factor analysis (CFA) by AMOS on the measurement models for the eight dimensions, including tourism involvement, tourism values, perception of ecotourism, affection toward ecotourism, attitude toward ecotourism, perceived value of ecotourism, willingness of consumers and actual ecotourism action.

Carmines \& MacIver (1981) proposed the ideal principle that fitness indicator should satisfy that ratio of chi-square value and degree of freedom $\leqslant 3$, that RMR and RMSEA should be lower than 0.05 , and that GFI, AGFI, NFI and CFI should be larger than 0.9. Sharma (1996) pointed out that fitness indicator is satisfied when GFI is larger than 0.8. Likewise, Forza \& Filippini (1998) suggested that the principle judgment can be accepted when AGFI is larger than 0.8. The results of study showed that in the fitness indicators of overall measurement model, $\chi^{2} / \mathrm{df}$ is 2.254 , GFI is 0.904 , AGFI is 0.876 , NFI is 0.953 , RFI is 0.942 , CFI is 0.973 , RMSEA is 0.040 and RMR is 0.076 . It can be inferred from above that the fitness of measurement model is within acceptable range, which indicates that the measurement model in this study has good fitness, construction validity and measurement efficiency.

\subsection{Comparison and Analysis of Multi-Group Competing Model}

For the 787 valid samples collected in this study, the ecotourism frequency was adopted as the clustering criterion. Respondents who participate in ecotourism at once every half year were in the high-frequency group, and there were 318 individuals in total; those who participate once a year were in the medium-frequency group, and there were 264 individuals in total; those who participate once every one and a half years or longer were in the low-medium group, and there were 205 individuals in total.

Based on AMOS, the group models of high-frequency, medium-frequency and low-frequency groups were compared and analyzed in order to investigate whether different groups have moderation effect on the association path. In the fitness of this competing model (as shown in Table 2), $\chi^{2} / \mathrm{df}$ is 2.434 , RMR is 0.263 , GFI is 0.808 , AGFI is 0.725 , NFI is 0.873 , RFI is 0.827 , CFI is 0.919 and RMSEA is 0.043 , all of which meet the criteria of good fitness. Therefore, the competing model in this study has good fitness, indicating that the model can be accepted. The analysis results and description are shown in Table 2:

(1). The influence path of affection toward ecotourism on perceived value of ecotourism is the most significant among the four independent variables in the three tourism groups, which indicates that consumers can perceive a relatively abundant value feedback from participating in ecotourism when they hold a relatively positive affection for ecological environment. 
(2) The influence path of perceived value of ecotourism on attitude toward ecotourism is the most significant among the mediating variables in the three tourism groups, which indicates that consumers hold a relatively positive attitude toward ecotourism when they perceive a higher value of ecotourism.

(3) The influence intensity (H1a) of the path from tourism involvement to attitude toward ecotourism differs significantly between high-frequency group and medium-frequency group $(\mathrm{t}=2.154)$. Specifically, the influence intensity of high-frequency group on this path (H1a) is higher than that of medium-frequency group $(-0.33>-0.138)$, both of which impose negative influences. It is indicated that although high-frequency group has certain preference for tourism, they hold a relatively negative attitude toward experience of ecotourism.

(4) The influence intensity ( $\mathrm{H} 2 \mathrm{~b})$ of the path from tourism values to perceived value of ecotourism differs significantly between high-frequency group and medium-frequency group $(\mathrm{t}=2.323)$. Specifically, the influence intensity of medium-frequency group on this path $(\mathrm{H} 2 \mathrm{~b})$ is higher than that of high-frequency group $(0.115>-0.106)$, and the influence intensity of medium-frequency group is positive, which indicates that the perceived value and satisfaction of medium-frequency group is influenced by individual tourism values during ecotourism.

(5) The influence intensity (H4a) of the path from affection toward ecotourism to attitude toward ecotourism differs significantly between high-frequency group and medium-frequency group ( $\mathrm{t}=1.995)$. Specifically, the influence intensity of medium-frequency group on this path (H4a) is higher than that of high-frequency group $(0.373>0.126)$, both of which impose positive influences. It is indicated that the medium-frequency group holds a strong affection for ecological environment, which affects their overall attitude toward ecotourism more significantly than that of high-frequency group.

(6) The influence intensity (H5) of the path from perceived value of ecotourism to attitude toward ecotourism differs significantly between high-frequency group and medium-frequency group ( $\mathrm{t}=-3.131)$. Specifically, the influence intensity of high-frequency group on this path (H5) is higher than that of medium-frequency group $(0.778>0.492)$, both of which impose positive influences. It is indicated that high-frequency group has a relatively obvious preference for ecotourism due to its knowledge connotation and experience during ecotourism.

(7) The influence intensity (H4a) of the path from affection toward ecotourism to attitude toward ecotourism differs significantly between medium-frequency group and low-frequency group $(t=-2.265)$. Specifically, the influence intensity of medium-frequency group on this path ( $\mathrm{H} 4 \mathrm{a})$ is higher than that of low-frequency group $(0.373>0.106)$, both of which impose positive influences. It is indicated that the medium-frequency group holds a strong affection for ecological environment, which affects their overall attitude toward ecotourism more significantly than that of low-frequency group.

(8) The influence intensity (H2b) of the path from tourism values to perceived value of ecotourism differs significantly between high-frequency group and low-frequency group $(\mathrm{t}=2.329)$. Specifically, the influence intensity of low-frequency group on this path $(\mathrm{H} 2 \mathrm{~b})$ is higher than that of high-frequency group $(0.087>-0.106)$, and the influence intensity of low-frequency group is positive, which indicates that the low-frequency group perceives a more obvious ecotourism value due to different individual views on tourism during ecotourism.

In summary, there are significant differences in six influence intensities among three tourism groups on each dimension, which indicates that some paths and association intensities differ obviously with different consumer tourism frequencies. Therefore, $\mathrm{H} 9$ is partially supported, which demonstrates that different tourism frequencies indeed lead to differences in association structure, which is a major finding of this study.

Table 2. Comparison and analysis of multi-group competing model

\begin{tabular}{|c|c|c|c|c|c|c|}
\hline \multirow[b]{2}{*}{ Path } & \multicolumn{3}{|c|}{ Evaluation value of standard parameters } & \multicolumn{3}{|c|}{ Comparative results of the $T$ test } \\
\hline & $\begin{array}{l}\text { High } \\
\text { frequency } \\
\text { group }\end{array}$ & $\begin{array}{l}\text { Medium } \\
\text { frequency group }\end{array}$ & $\begin{array}{l}\text { Low } \\
\text { frequency } \\
\text { group }\end{array}$ & $\begin{array}{l}\text { High } \\
\text { vs } \\
\text { Medium }\end{array}$ & $\begin{array}{l}\text { Medium vs } \\
\text { Low }\end{array}$ & $\begin{array}{l}\text { High } \\
\text { vs } \\
\text { Low }\end{array}$ \\
\hline $\begin{array}{l}\text { H1a: Tourism involvement } \\
\quad \rightarrow \text { Attitude toward ecotourism }\end{array}$ & $\begin{array}{l}-0.33 \\
* * *\end{array}$ & $\begin{array}{l}-0.138 \\
* *\end{array}$ & $\begin{array}{l}-0.161 \\
* * *\end{array}$ & $\begin{array}{l}2.154 \\
* *\end{array}$ & -0.632 & 1.424 \\
\hline $\begin{array}{l}\text { H1b: Tourism involvement } \\
\quad \rightarrow \text { Perceived value of ecotourism }\end{array}$ & $\begin{array}{l}0.55 \\
* * *\end{array}$ & $\begin{array}{l}0.456 \\
* * *\end{array}$ & $\begin{array}{l}0.383 \\
* * *\end{array}$ & -0.187 & -0.221 & -0.448 \\
\hline $\begin{array}{l}\text { H2a: Tourism values } \\
\quad \rightarrow \text { Attitude toward ecotourism }\end{array}$ & $\begin{array}{l}0.15 \\
* * *\end{array}$ & 0.013 & $\begin{array}{l}0.134 \\
* * *\end{array}$ & -1.766 & 1.622 & -0.292 \\
\hline $\begin{array}{l}\text { H2b: Tourism values } \\
\quad \rightarrow \text { Perceived value of ecotourism }\end{array}$ & $\begin{array}{l}-0.106 \\
*\end{array}$ & 0.115 & 0.087 & $\begin{array}{l}2.323 \\
* *\end{array}$ & -0.501 & $\begin{array}{l}2.329 \\
* *\end{array}$ \\
\hline
\end{tabular}




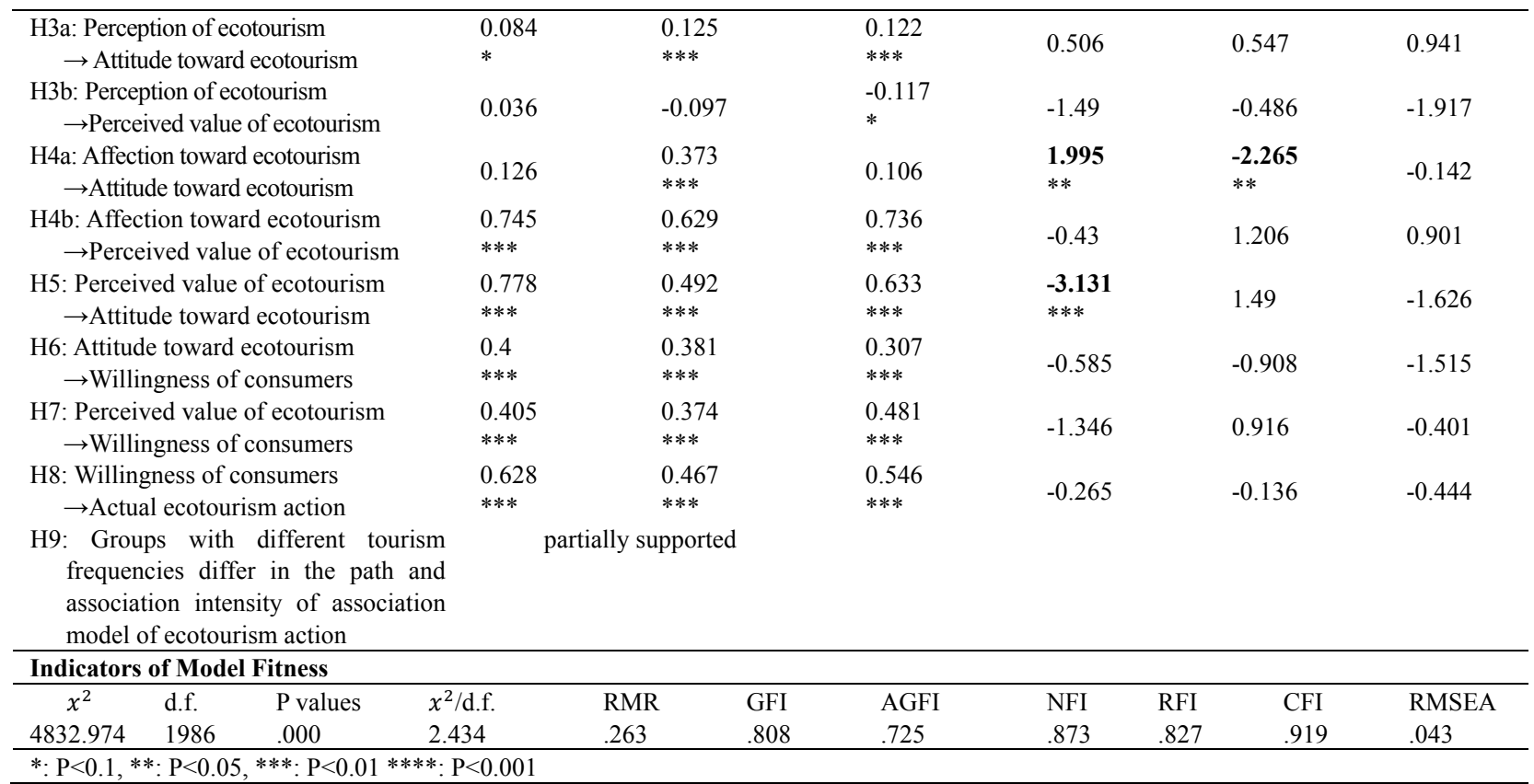

\section{Conclusion and Suggestions}

\subsection{Conclusion}

This study investigated the individuals who had participated in ecotourism, in order to explore the influences of tourism involvement, tourism values, perception of ecotourism and affection toward ecotourism on their attitude toward ecotourism, perceived value of ecotourism, willingness, and actual ecotourism action. The association models were established, and the differences among groups with different tourism frequencies were compared. The conclusions are as follows:

(1). Among the four independent variables, affection toward ecotourism of three tourism groups has the highest influence on perceived value of ecotourism, which indicates that tourists feel relatively pleased and at ease if the ecotourism can create a relatively comfortable ecological experiential space on the overall environmental planning, such as walking path, observation desk and nature, etc. Tourists can also obtain in-depth experience in the nature from ecotourism, and further desire to understand more related ecological and environmental knowledge.

(2). Three tourism groups have a significantly negative influence on the path from tourism involvement to attitude toward ecotourism, and the influence of high-frequency group is the highest. This suggests that although high-frequency tourists favor tourism, they still hold a relatively negative feeling toward ecotourism. On one hand, the ecotourism regions are more remote than other scenic spots, thus requiring more time and efforts to reach the destinations. On the other hand, the environments in many ecotourism regions in Taiwan have been destroyed and polluted by manmade activities in recent years. For instance, Kenting Shirding tribe noticed that tourists barbecue, carve on stones, pick flowers and branches, throw stones at sika deer and dump garbage in ecological regions. There are also damages to Penghu sea area, where $500 \mathrm{~kg}$ of fishing net has been collected, which endangers the habitat of coral reef. The long-term accumulated pollution has left a poor impression on tourists with high tourism frequency.

(3). High-frequency group has a significantly negative influence on the path from tourism values to perceived value of ecotourism. One of the possible reasons is that ecotourism rather lacks interaction or attraction compared to other tourism activities. Considering that there have not been significant changes to the ecological environment in Taiwan for many years, high-frequency tourists lack a sense of freshness and can only acquire a relatively lower experiential value. However, medium-frequency and low-frequency tourist groups are not significantly influenced, which indicates that these groups have less contact with ecotourism and thus might not understand the abundance value that ecotourism can offer them.

(4). The medium-frequency group has a significantly positive influence on the path from affection toward ecotourism to attitude toward ecotourism, and their influence intensity is the highest, which indicates that although medium-frequency tourists favor tourism, their tourism frequency might be limited by economic and 
working factors. Therefore, before each tourism experience, they would collect related information more carefully and arrange the tourism attentively in order to relieve their stress (Pollster, 2009). Hence, this group can feel pleased in abundant ecological scenic spot, thereby improving the attitude toward ecotourism. However, high-frequency and low-frequency tourism groups are not significantly influenced, which indicates that high-frequency tourism group might try other forms of tourism due to ecotourism experience; however, low-frequency tourism group still keeps skeptical of ecotourism due to possible lack in understanding of ecotourism.

(5). Three tourism groups have a significantly positive influence on the path from perceived value of ecotourism to attitude toward ecotourism, and the influence intensity of high-frequency group is the highest, which indicates that the knowledge connotation and experience provided by ecotourism for high-frequency tourism group are more abundant, and that they hold a relatively obvious preference for ecotourism. The main reason is that this group not only hopes to enrich their spiritual world through tourism but emphasizes more on the opportunity to broaden their horizons in tourism (Mastercard Worldwide, 2015).

\subsection{Management Implication}

The comparison results of linear structural model in this study indicated that there are both similarities and differences among groups with different tourism frequencies. Therefore, the following managerial directions and suggestions are proposed.

Considering that the influence of affection toward ecotourism on perceived value of ecotourism is the most significant among the four independent variables in the three tourism groups, it is suggested that governmental authorities and tour operators should firstly limit crowd control on the itinerary planning of ecological environment in order to prevent congestion from reducing tourism quality when the tourists are walking. They should also legally restrain the street vendors from interfering with natural scenery. In addition, they can organize themed events and improve interactions between tourists and ecological environment in combination of ecological cultures, such as the Swim across the Sun Moon Lake held by Yuchih Township of Nantou County, and Lungshan Three Treasury Cultural Festival held by Lungshan of Qigu Township. These events can allow consumers to participate, improve the abundance of the overall tourism value, and promote ecotourism.

Three tourism groups have a significantly negative influence on the path from tourism involvement to attitude toward ecotourism, and the influence of the high-frequency tourism group is the highest, which indicates that this group holds unfavorable impressions on ecotourism during previous tourism experience. For instance, ecotourism costs a huge amount of efforts and time, ecological environments are damaged and excessively commercialized, covering up the natural scenery. This study suggests that governmental authorities and tour operators should cooperate with transportation providers to improve more diverse and convenient means of transportation for consumers, thus reducing the efforts and time in information search. In addition, the priority should be to preserve the ecological environments, and commercial behaviors, including excessive reclamation, damage and covering up of natural scenery, should be forbidden.

Considering that high-frequency tourism group has a significantly negative influence on the path from tourism values to perceived value of ecotourism, while medium-frequency and low-frequency tourism groups have no significant influence. It is suggested that ecotourism packages should be promoted in cooperation with local communities and tribes, such as oyster harvest in Fangyuan Township of Changhua County. By resource integration, oxcarts are used as transportation, and local residents are recruited as tour guides to promote ecotourism and create a three-win situation for residents, tourists and environments. In the aspect of marketing, Facebook can be set up and community can be established to enhance media exposure channels. Besides, the ecotourism can be exposed by bloggers and media.

Medium-frequency tourism group has a significantly positive influence on the path from affection toward ecotourism to attitude toward ecotourism, and the influence of this group is the highest while affection toward ecotourism of high-frequency and low-frequency groups has no significant influence. Considering that medium-frequency tourism group collect related information more attentively before departure, it is suggested that governmental authorities and tour operators should firstly strengthen commodity information and increase the features and abundance of website contents by posting films, photos and live streaming. In addition, bloggers can be invited to write the related reports on ecotourism experience and share the featured customs in ecological scenic spots.

Considering that three tourism groups have a significantly positive influence on the path from perceived value of ecotourism to attitude toward ecotourism and the influence of high-frequency tourism group is the highest, it is suggested that governmental authorities and tour operators should improve the guide and interpretation service 
of ecotourism or issue ecotourism App to enable consumer to book tour guide service before departure, thus making ecotourism more profound and creating more satisfying tourism experience.

\subsection{Research Limitations and Suggestions for Future Research}

Considering that many factors influence the actual ecotourism action of consumers, this study only probed into tourism involvement, tourism values, perception of ecotourism and affection toward ecotourism. More variables can be added in the future to make the association model more perfect. As the ecotourism scope involved in this study is broad, certain specific natural ecological park area and consumers in different age groups can be investigated in depth in the future in order to discuss the differences in consumer groups for different ecotourism park areas. In addition, the association model established in this study can be applied in other different types of tourism modes, which makes the conceptual structure of this study more universal.

\section{References}

Ajzen, I., \& Fishbein, M. (1980). Understanding Attitudes and Predicting Social Behaviour. Englewood Cliffs, N.J.: Prentice-Hall.

Andrews, J. C., Durvasula, S., \& Akhter, S. H. (1990). A framework for conceptualizing and measuring the involvement construct in advertising research. Journal of Advertising, 19(4), 27-40. https://doi.org/10.1080/00913367.1990.10673198

Arnould, E., Price, L., \& Zinkhan, G. (2004). Consumers (2nd ed.). New York: Mcgraw-Hill.

Assael, H. (1998). Consumer Behavior and Marketing Action. Cincinnati, Ohio: South-western College Pub.

Babin, B. J., \& Darden, W. R. (1995). Consumer self-regulation in a retail environment. Journal of Retailing, 71(1), 47-70. https://doi.org/10.1016/0022-4359(95)90012-8

Bagozzi, R. P., Gopinath, M., \& Nyer, P. U. (1999). The role of emotions in marketing. Journal of the Academy of Marketing Science, 27(2), 184-206. https://doi.org/10.1177/0092070399272005

Barbaro, N., Pickett, S. M., \& Parkhill, M. R. (2015). Environmental attitudes mediate the link between need for cognition and pro-environmental goal choice. Personality and Individual Differences, 75, 220-223. https://doi.org/10.1016/j.paid.2014.11.032

Bascomb, B., \& Taylor, M. (2008). Ecotourism and Sustainability in a Q'eqchi 'Maya Community, Guatemala. Focus on Geography, 51(3), 11-16. https://doi.org/10.1111/j.1949-8535.2008.tb00228.x

Bjork, P. (2000). Ecotourism from a conceptual perspective, an extended definition of a unique tourism form. $\begin{array}{lllll}\text { The International Journal of Tourism Research, } & 189 .\end{array}$ https://doi.org/10.1002/(SICI)1522-1970(200005/06)2:3<189::AID-JTR195>3.0.CO;2-T

Bjorner, T. B., Hansen, L. G., \& Russell, C. S. (2004). Environmental labeling and consumer's choice-An empirical analysis of the effect of the Nordic Swan. Journal of Environmental Economics and Management, 47(3), 411-434. https://doi.org/10.1016/j.jeem.2003.06.002

Bloch, P. H., \& Richins, M. L. (1983). A theoretical model for the study of product importance perceptions. The Journal of Marketing, 47(3) 69-81. https://doi.org/10.2307/1251198

Boulding, W., Kalra, A., Staelin, R., \& Zeithaml, V. A. (1993). A dynamic process model of service quality: from expectations to behavioral intentions. Journal of Marketing Research, 30(1), 7. https://doi.org/10.2307/3172510

Buckley, R. (1994). A framework for ecotourism. Annals of Tourism Research, 21(3), 661-665. https://doi.org/10.1016/0160-7383(94)90126-0

Chawla, L. (1998). Significant life experience revisited: A review of research on sources of environment sensitivity. Environmental Education Research, 4(4), 369-382. https://doi.org/10.1080/1350462980040402

Chernela, J. M. (2011). Barriers natural and unnatural: islamiento as a central metaphor in Kuna ecotourism. Bulletin of Latin American Research, 30(1), 35-49. https://doi.org/10.1111/j.1470-9856.2010.00447.x

Cronin Jr, J. J., \& Taylor, S. A. (1992). Measuring service quality: a reexamination and extension. The Journal of Marketing, 56(3) 55-68. https://doi.org/10.2307/1252296

Cronin, J. J., Brady, M. K., \& Hult, G. T. M. (2000). Assessing the effects of quality, value, and customer satisfaction on consumer behavioral intentions in service environments. Journal of Retailing, 76(2), 193-218. https://doi.org/10.1016/S0022-4359(00)00028-2 
Carmines, E. G. (1981). Analyzing models with unobserved variables. Social Measurement: Current Issues, 80, $65-115$

Ceballos, L. H. (1987). The future of ecotourism. Mexico Journal, 1(987), 13-14.

Davis, F. D. (1989). Perceived usefulness, perceived ease of use, and user acceptance of information technology. MIS Quarterly, 13, 319-340. https://doi.org/10.2307/249008

Dodds, W. B. (1985). An Experimental Investigation of the Effects of Price, Brand and Store Information on the Subjective Evaluation of Products (Perception, Name, Quality). Ph.D. dissertation, Virginia Polytechnic Institute and State University.

Durgee, J. F., O’Connor, G. C., \& Veryzer, R. W. (1996). Translating values into product wants. Journal of Advertising Research, 36(6), 90-101.

Eagles, J. F., \& Blackwell, R. D. (1995). Consumer Behavior. Chicago: Dryden Press.

Engel, J. F., Blackwell, R. D., \& Miniard, P. W. (2001). Consumer Behavior (p. 218). New York: The Dryden.

Elias, W., Benjamin, J., \& Shiftan, Y. (2015). Gender differences in activity and travel behavior in the Arab world. Transport Policy, 44, 19-27. https://doi.org/10.1016/j.tranpol.2015.07.001

Fabrício, S. M., \& Sidnei, R. (2017). The results of ecotourism policies in protected areas in Brazil and Canada. Revista Brasileira de Pesquisa em Turismo, 11(3), 454-479.

Feather, N. T., \& Rauter, K. A. (2004). Organizational citizenship behaviours in relation to job status, job insecurity, organizational commitment and identification, job satisfaction and work values. Journal of Occupational and Organizational Psychology, 77(1), 81-94. https://doi.org/10.1348/096317904322915928

Forza, C., \& Filippini, R. (1998). TQM impact on quality conformance and customer satisfaction: A causal model. International Journal of Production Economics, 55(1), 1-20. https://doi.org/10.1016/S0925-5273(98)00007-3

Fennell, D. A. (2001). A content analysis of ecotourism definitions. Current Issues in Tourism, 4(5), 403-421. https://doi.org/10.1080/13683500108667896

Fisher, J. D., \& Bell, P. A. B. (1984). Environmental Psychology (pp. 18-57). New York: CBS College.

Folkes, V. S. (1988). Recent attribution research in consumer behavior: A review and new directions. Journal of Consumer Research, 14(4), 548-565. https://doi.org/10.1086/209135

Frijda, N. H. (1993). Moods, emotion episodes, and emotions. In M. Lewis \& J. M. Haviland (Eds.), Handbook of Emotions (pp. 318-403). New York: Guilford Press.

Funk, D. C., Ridinger, L. L., \& Moorman, A. M. (2004). Exploring origins of involvement: Understanding the relationship between consumer motives and involvement with professional sport teams. Leisure Sciences, 26(1), 35-61. https://doi.org/10.1080/01490400490272440

Fornell, C. R., \& Larcker, F. F. (1981). Structural equation models with unobservable variables and measurement error. Journal of Marketing Research, 18, 39-51. https://doi.org/10.2307/3151312

Grewal, D., Monroe, K. B., \& Krishnan, R. (1998). The effects of price-comparison advertising on buyers perceptions of acquisition value, transaction value, and behavioral intentions. The Journal of Marketing, 62, 46-59. https://doi.org/10.2307/1252160

Gaski, J. F., \& Nevin, J. R. (1985). The differential effects of exercised and unexercised power sources in a marketing channel. Journal of Marketing Research, 22(2), 130-142. https://doi.org/10.2307/3151359

Hanna, N., \& Wozniak, R. (2001). Consumer Behavior (1th ed.). New Jer-sey: Prentice-Hall.

Hellier, P. K., Geursen, G. M., Carr, R. A., \& Rickard, J. A. (2003). Customer repurchase intention: A general structural equation model. European Journal of Marketing, 37(11/12), 1762-1800. https://doi.org/10.1108/03090560310495456

Havitz, M. E., \& Dimanche, F. (1990). Propositions for testing the involvement construct in recreational and tourism contexts. Leisure Sciences, 12(2), 179-195. https://doi.org/10.1080/01490409009513099

Hetzer, N. D. (1965). Environment, tourism, culture. Links (July): Reprint in Ecosphere, 1(2), 1-3.

Hirschman, E. C., \& Holbrook, M. B. (1982). Hedonic consumption: emerging concepts, methods and propositions. The Journal of Marketing, 46, 92-101. https://doi.org/10.2307/1251707 
Hair, J. F., Tatham, R. L., Anderson, R. E., \& Black, W. (2006). Multivariate Data Analysis (4th ed.). New Jersey: Prentice Hall.

Homer, P. M., \& Kahle, L. R. (1988). A structural equation test of the value-attitude-behavior hierarchy. Journal of Personality and Social Psychology, 54(4), 638. https://doi.org/10.1037/0022-3514.54.4.638

Horng, J. S., Liu, C. H., Chou, H. Y., \& Tsai, C. Y. (2012). Understanding the impact of culinary brand equity and destination familiarity on travel intentions. Tourism Management, 33(4), 815-824. https://doi.org/10.1016/j.tourman.2011.09.004

Iwasaki, Y., \& Havitz, M. E. (2004). Examining relationships between leisure involvement, psychological commitment and loyalty to a recreation agency. Journal of Leisure Research, 36(1), 45. https://doi.org/10.1080/00222216.2004.11950010

Johnson, M. D., Herrmann, A., \& Huber, F. (2006). The evolution of loyalty intentions. Journal of Marketing, 70(2), 122-132. https://doi.org/10.1509/jmkg.70.2.122

Kelly, J. R. (1983). Leisure Identities and Interactions. London: George Allen \& Unwin.

Kotler, P., \& Keller, K. L. (2009). Dirección de marketing. Harlow: Pearson educación.

King, S. C., \& Meiselman, H. L. (2010). Development of a method to measure consumer emotions associated with foods. Food Quality and Preference, 21(2), 168-177. https://doi.org/10.1016/j.foodqual.2009.02.005

Kozak, M. (2001). Comparative assessment of tourist satisfaction with destinations across two nationalities. Tourism Management, 22(4), 391-401. https://doi.org/10.1016/S0261-5177(00)00064-9

Kumar, A., Lee, H. J., \& Kim, Y. K. (2009). Indian consumers' purchase intention toward a United States versus local brand. Journal of Business Research, 62(5), 521-527. https://doi.org/10.1016/j.jbusres.2008.06.018

Kyle, G. T., \& Mowen, A. J. (2005). An examination of the leisure involvement-agency commitment relationship. Journal of Leisure Research, 37(3), 342. https://doi.org/10.1080/00222216.2005.11950057

Kerlinger, F. N. (1978). Foundation of Behavioral Research. New York: McGraw-Hill.

Lafferty, B. A., Goldsmith, R. E., \& Newell, S. J. (2002). The dual credibility model: The influence of corporate and endorser credibility on attitudes and purchase intentions. Journal of Marketing Theory and Practice, 10(3), 1-11. https://doi.org/10.1080/10696679.2002.11501916

Lai, P. H., \& Nepal, S. K. (2006). Local perspectives of ecotourism development in Tawushan Nature Reserve, Taiwan. Tourism Management, 27(6), 1117-1129. https://doi.org/10.1016/j.tourman.2005.11.010

Laurent, G., \& Kapferer, J. N. (1985). Measuring consumer involvement profiles. Journal of Marketing Research, 22, 41-53. https://doi.org/10.2307/3151549

Li, C. L. (2010). Is leisure studies "ethnocentric"? A view from Taichung, Taiwan. World Leisure Journal, 52(3), 196-199. https://doi.org/10.1080/04419057.2010.9728282

Losada, N., Alén, E., Domínguez, T., \& Nicolau, J. L. (2016). Travel frequency of seniors tourists. Tourism Management, 53, 88-95. https://doi.org/10.1016/j.tourman.2015.09.013

Lien, C. H., Wen, M. J., Huang, L. C., \& Wu, K. L. (2015). Online hotel booking: The effects of brand image, price, trust and value on purchase intentions. Asia Pacific Management Review, 20(4), 210-218. https://doi.org/10.1016/j.apmrv.2015.03.005

Lovelock, C., \& Wirtz, J. (2004). Services Marketing: People, Technology, Strategy (5th ed.). Upper Saddle River, New Jersey: Pearson Prentice Hall.

Lucy, A., \& Njoroge, J. M. (2018). The ecotourism metaphor and environmental sustainability in Kenya. Tourism \& Hospitality Research, 18(1), 49-60. https://doi.org/10.1177/1467358415619671

Madrigal, R. (1995). Residents' perceptions and the role of government. Annals of Tourism Research, 22(1), 86-102. https://doi.org/10.1016/0160-7383(94)00070-9

Mehrabian, A., \& Russell, J. A. (1974). An Approach to Environmental Psychology. CM: MIT Press.

Mintz, S. M. (1995). Virtue ethics and accounting education. Issues in Accounting Education, 10(2), 247.

Morwitz, V. G., \& Schmittlein, D. (1992). Using segmentation to improve sales forecasts based on purchase intent: Which "intenders" actually buy? Journal of Marketing Research, 29, 391-405. https://doi.org/10.2307/3172706 
Mulhern, F. J. (1999), Customer Profitability Analysis: Measurement, Concentration, and Research Directions. $\begin{array}{lllll}\text { Journal of } & \text { Interactive } & \text { 25-40. }\end{array}$ https://doi.org/10.1002/(SICI)1520-6653(199924)13:1<25::AID-DIR3>3.0.CO;2-L

Nunnally, J. C. (1978). Psychometric Theory. New York: McGraw-Hill.

Park, S. H. (1996). Relationships between involvement and attitudinal loyalty constructs in adult fitness programs. Journal of Leisure Research, 28(4), 233. https://doi.org/10.1080/00222216.1996.11949774

Petrick, J. F. (2002). Development of a multi-dimensional scale for measuring the perceived value of a service. Journal of Leisure Research, 34(2), 119. https://doi.org/10.1080/00222216.2002.11949965

Petty, R. E., Cacioppo, J. T., Kao, C. F., \& Rodrigues, R. (1986). Central and peripheral routes to persuasion: An individual difference perspective. Journal of Personality and Social Psychology, 51(5), 1032-1043. https://doi.org/10.1037/0022-3514.51.5.1032

Pine, G. J., \& Innis, G. (1987). Cultural and individual work values. The Career Development Quarterly, 35(4), 279-287. https://doi.org/10.1002/j.2161-0045.1987.tb00926.x

Ponte, E. B., Carvajal-Trujillo, E., \& Escobar-Rodríguez, T. (2015). Influence of trust and perceived value on the intention to purchase travel online: Integrating the effects of assurance on trust antecedents. Tourism Management, 47, 286-302. https://doi.org/10.1016/j.tourman.2014.10.009

Pike, S., \& Ryan, C. (2004), Destination positioning analysis through a comparison of cognitive, affective, and conative perceptions. Journal of Travel Research, 42(2), 333-342. https://doi.org/10.1177/0047287504263029

Ragheb, M. G., \& Beard, J. G. (1982). Measuring leisure attitude. Journal of Leisure Research, 14(2), 155. https://doi.org/10.1080/00222216.1982.11969512

Reed, S. K. (2012). Cognition: Theories and Applications (pp. 18-26). USA: CENGAGE learning.

Robbins, S. P. (2001). Organizational Behavior (9th ed.). New York: Prentic Hall.

Rokeach, M. (1973). The Nature of Human Values (pp. 12-16). New York: Free Press.

Rosenberg, M. J., Hovland, C. I., McGuire, W. J., Abelson, R. P., \& Brehm, J. W. (1960). Attitudes Organization and Change (pp. 15-64). New Haven: Yale University Press.

Russell, J. A., \& Pratt, G. (1980). A description of the affective quality attributed to environments. Journal of Personality and Social Psychology, 38(2), 311. http://dx.doi.org/10.1037/0022-3514.38.2.311

Schiffman, L. G., \& Kanuk, L. L. (2000). Consumer Behavior (7th ed.). NY: Prentice Hall.

Schwartz, S. H. (1992). Universals in the content and structure of values: Theoretical advances and empirical tests in 20 countries. Advances in Experimental Social Psychology, 25, 1-65. https://doi.org/10.1016/S0065-2601(08)60281-6

Sherry Jr, J. F. (1990). Dealers and dealing in a periodic market: informal retailing in ethnographic perspective. Journal of Retailing, 66(2), 174-200.

Sheth, J. N., Newman, B. I., \& Gross, B. L. (1991). Why we buy what we buy: A theory of consumption values. Journal of Business Research, 22(2), 159-170. https://doi.org/10.1016/0148-2963(91)90050-8

Sharma, S. (1996). Applied Multivariate Techniques (1th ed.). New York: Wiley.

Shim, S., Eastlick, M. A., Lotz, S. L., \& Warrington, P. (2001). An online prepurchase intentions model: The role of intention to search: Best Overall Paper Award-The Sixth Triennial AMS/ACRA Retailing Conference, 200011 Decision made by a panel of Journal of Retailing editorial board members. Journal of Retailing, 77(3), 397-416. https://doi.org/10.1016/S0022-4359(01)00051-3

Sia, C. L., Lim, K. H., Leung, K., Lee, M. K., Huang, W. W., \& Benbasat, I. (2009). Web strategies to promote internet shopping: is cultural-customization needed? MIS Quarterly, 33, 491-512. https://doi.org/10.2307/20650306

Singhapakdi, A., \& Vitell, S. J. (1993). Personal and professional values underlying the ethical judgments of marketers. Journal of Business Ethics, 12(7), 525-533. https://doi.org/10.1007/BF00872374

Smith, R. E., \& Swinyard, W. R. (1982). Information response models: An integrated approach. The Journal of Marketing, 16, 81-93. https://doi.org/10.2307/1251162

Smith, S. M., Haugtvedt, C. P., \& Petty, R. L. (1994). Need for Cognition and the Effects of Repeated Expression 
on Attitude Accessibility and Extremity. Advances in Consumer Research, 21(1), 234-237.

Stone, R. N. (1984). The marketing characteristics of involvement. NA-Advances in Consumer Research, (11), 210-215.

Sutton, W. A., McDonald, M. A., Milne, G. R., \& Cimperman, J. (1997). Creating and fostering fan identification in professional sports. Sport Marketing Quarterly, 6, 15-22.

Swanson, E. B. (1974). Management information systems: appreciation and involvement. Management Science, 21(2), 178-188. https://doi.org/10.1287/mnsc.21.2.178

Sweeney, J. C., \& Soutar, G. N. (2001). Consumer perceived value: The development of a multiple item scale. Journal of Retailing, 77(2), 203-220. https://doi.org/10.1016/S0022-4359(01)00041-0

Swinyard, W. R. (1993). The effects of mood, involvement, and quality of store experience on shopping intentions. Journal of Consumer Research, 20(2), 271-280. https://doi.org/10.1086/209348

Thaler, R. (1985). Mental accounting and consumer choice. Marketing Science, 4(3), $199-214$. https://doi.org/10.1287/mksc.4.3.199

Venkatesh, V., \& Agarwal, R. (2006). Turning visitors into customers: a usability-centric perspective on purchase behavior in electronic channels. Management Science, 52(3), $367-382$. https://doi.org/10.1287/mnsc. 1050.0442

Weber, A. L., (1991). Introduction to Psychology. Harper Collins College, NewYork.

Wiley, C. G., Shaw, S. M., \& Havitz, M. E. (2000). Men's and women's involvement in sports: An examination of the gendered aspects of leisure involvement. Leisure Sciences, 22(1), 19-31. https://doi.org/10.1080/014904000272939

Williams Jr, R. M. (1979). Change and stability in values and value systems: A sociological perspective. Understanding Human Values, 15, 46.

Wells, W. D., \& Prensky, D. (1996). Consumer Behavior. NY: John Wiley and Sons Inc.

$\mathrm{Wu}$, S. I. (2006). A comparison of the behavior of different customer clusters towards Internet bookstores. Information and Management, 43(8), 986-1001. https://doi.org/10.1016/j.im.2006.09.002

Yoon, Y., Gursoy, D., \& Chen, J. S. (2001). Validating a tourism development theory with structural equation modeling. Tourism Management, 22(4), 363-372. https://doi.org/10.1016/S0261-5177(00)00062-5

Zaichkowsky, J. L. (1985). Measuring the involvement construct. Journal of Consumer Research, 12(3), 341-352. https://doi.org/10.1086/208520

Zajonc, R. B., \& Markus, H. (1982). Affective and cognitive factors in preferences. Journal of Consumer Research, 9(2), 123-131. https://doi.org/10.1086/208905

Zeithaml, V. A. (1988). Consumer perceptions of price, quality, and value: a means-end model and synthesis of evidence. The Journal of Marketing, 52, 2-22. https://doi.org/10.2307/1251446

Zeithaml, V. A., Berry, L. L., \& Parasuraman, A. (1996). The behavioral consequences of service quality. The Journal of Marketing, 60, 31-46. https://doi.org/10.2307/1251929

Zins, A. H. (1998). Leisure traveler choice models of theme hotels using psychographics. Journal of Travel Research, 36(4), 3-15. https://doi.org/10.1177/004728759803600401

Zhan, G., Yan, X., Zhu, S., \& Wang, Y. (2016). Using hierarchical tree-based regression model to examine university student travel frequency and mode choice patterns in China. Transport Policy, 45, 55-65. https://doi.org/10.1016/j.tranpol.2015.09.006

\section{Copyrights}

Copyright for this article is retained by the author, with first publication rights granted to the journal.

This is an open-access article distributed under the terms and conditions of the Creative Commons Attribution license (http://creativecommons.org/licenses/by/4.0/). 